\title{
Pertumbuhan dan Produktivitas Beberapa Galur Tanaman Padi (Oryza sativa L.) Pada Musim Tanam Gadu
}

(The growth and productivity of some rice strains on dry planting seasons)

\author{
Ahmad Amri ${ }^{1}$, Sabaruddin ${ }^{1}$, Marai Rahmawati ${ }^{1}$ \\ ${ }^{1}$ Program Studi Agroteknologi, Fakultas Pertanian, Universitas Syiah Kuala \\ ${ }^{2}$ Jurusan Agroteknologi, Fakultas Pertanian, Universitas Syiah Kuala
}

\begin{abstract}
Abstrak. Penelitian ini bertujuan mengetahui pertumbuhan dan produktivitas beberapa galur tanaman padi pada musim tanam gadu. Penelitian ini dilaksanakan di lahan sawah BBT (Balai Benih Terpadu) Samahani Kecamatan Kuta Malaka Kabupaten Aceh Besar Provinsi Aceh, yang berlangsung mulai bulan Mai sampain bulan Oktober 2015. Penelitian ini menggunakan Rancangan Acak Kelompok (RAK) nonfaktorial dengan 3 galur padi yaitu: 14 E 1002, 11S3, 14 E 1009 dan masing-masing diulang 3 kali, sehingga terdapat 9 satuan percobaan.Peubah yang diamati melitputi tinggi tanaman dan jumlah anakan padi umur 2, 3, 4, 5, 6, dan 7 minggu setelah tanam (MST), umur berbunga, umur panen, panjang malai, berat 1000 butir gabah, persentase gabah berisi per rumpun, persentase gabah hampa per rumpu, berat gabah berisi per rumpun, berat gabah berisi per plot, dan potensi hasil. Terdapat perbedaan pertumbuhan dan produktivitas tinggi tanaman, panjang malai dan berat 1000 . Tanaman tertinggi dijumpai pada galur 14E1002, malai terpanjang dijumpai pada galur 11S3 dan berat 1000 butir tertinggi terdapat pada galur 11S3. Galur 14E1009 dalam mencapai hasil per hektar lebih tinggi yaitu 7,43 ton per hektar pada musim tanam gadu.
\end{abstract}

Kata kunci : Pertumbuhan, produktivitas, padi, galur, musim tanam gadu

\begin{abstract}
This research aims to know the growth and productivity of some strains of rice plant on dry planting season. This research was carried out in a BBT paddy fields (Integrated Seed Hall) Samahani Kuta Malaka, Aceh Besar Regency of Aceh Province, from Mai to October 2015. This study used a Randomized Design Group- nonfactor with 3 strains of rice that is: 141002 E, 11S3 E, 141009 and each repeated 3 times, so there are 9 units of the experiment. The observed variables are plant height and tillers of 2, 3, 4, 5, 6, and 7 weeks after planting, flowering age, age of harvest, panicle length, the weight of 1000 grains of paddy, the percentage of grain contains per clump, the percentage of empty grain per tiller, heavy grain contains per clump, heavy grain contains per plot, and potential yield. There is a difference in growth and high productivity of plants, the length and weight of 1000 the panicle. The tallest plants found in strain14E1002, longest panicle found in strains of 11S3 and a weight of 1000 grains found in the highest strain 11S3. Strain 14E1009 in achieving higher per hectare results 7.43 tonnes per hectare at dry planting season.
\end{abstract}

Keywords: growth, productivity, rice,strain, dry planting season

\section{PENDAHULUAN}

Kebutuhan akan beras terus meningkat dari tahun ke tahun akibat terjadinya peningkatan konsumsi dan jumlah penduduk. Kebutuhan beras pada tahun 2015, perkiraan produksi padi di Indonesia sebanyak 75,55 juta ton Gabah Kering Giling (GKG) atau setara dengan 43,940 juta ton beras (Badan Pusat Statistik, 2015). Salah satu permasalahan dalam peningkatan produksi padi adalah mendapatkan galur atau varietas yang mempunyai daya adaptasi yang tinggi sehingga mampu menghasilkan produksi yang maksimum pada berbagai kondisi lingkungan. 
Peningkatan produktivitas padi sawah melonjak tajam setelah tahun 1977. Namun, peningkatan produktivitas mulai melandai pada tahun 1985-2000, yang menandakan semakin sempitnya keragaman genetik potensi hasil varietas yang telah dilepas. Untuk mengantisipasi melonjaknya kebutuhan beras di masa sekarang dan yang akan datang, perbaikan potensi hasil padi mutlak diperlukan. Wujud nyata terobosan perakitan varietas padi untuk masa yang akan datang adalah pengembangan padi tipe baru (Daradjat et al., 2001).

Untuk meningkatkan produksi dan pendapatan petani perlu upaya untuk mendapatkan varietas unggul baru spesifik lokasi melalui uji multilokasi dan stabilitas hasil galur harapan, ataupun mendapatkan galur potensial yang diperoleh melalui berbagai teknik pemuliaan tanaman. Pembentukan varietas unggul baru dituntut memiliki keunggulan yang semakin beragam dan atau semakin spesifik, sesuai dengan agroekosistem, permasalahan di lapangan, lokasi spesifik dan pilihan konsumen atau pengguna. Berkaitan dengan hal tersebut salah satu usaha untuk memperoleh varietas unggul baru dengan cara mengevaluasi pertumbuhan dan produktivitas beberapa galur potensial tanaman padi yang di tanam pada musim tanam gadu. Musim tanam gadu adalah musim tanam yang mengandalkan air hujan atau disebut juga sawah tadah hujan (Simanulang et al. 1995).

Untuk mengetahui pertumbuhan dan produktivitas beberapa galur potensial yang akan menghasilkan varietas unggul baru, maka perlu dilakukan uji hasil galur potensial untuk mengetahui pertumbuhan dan potensi hasil yang dapat diperoleh sebelum dilepaskan ke masyarakat umum. Uji daya hasil merupakan tahap penting dalam perakitan varietas. Galurgalur yang sudah mantap dan mempunyai sifat-sifat yang diharapkan perlu dievaluasi daya hasil dan keragamannya pada berbagai lokasi. Galur-galur yang berdaya hasil tinggi pada berbagai lokasi dapat diusulkan sebagai varietas unggul baru dengan daya adaptasi luas (Sudarna, 2010). Acquaah (2007) menyatakan bahwa uji daya hasil meliputi tiga tahap, yaitu uji daya hasil pendahuluan (UDHP), uji daya hasil lanjutan (UDHL), dan uji multilokasi untuk melihat stabilitas dan adaptabilitas tanaman di berbagai lokasi sebelum dilepas menjadi varietas unggul baru dengan karakter-karakter yang dikehendaki.

\section{METODE PENELITIAN}

Penelitian ini dilaksanakan di lahan sawah BBT (Balai Benih Terpadu) Samahani Kecamatan Kuta Malaka Kabupaten Aceh Besar Provinsi Aceh. Pelaksanaan penelitian ini di mulai pada bulan Mei sampai bulan Oktober 2015. Alat yang digunakan dalam penelitian ini adalah cangkul, garu, pisau, sprayer, ember, handuk, mistar/meteran, timbangan, papan nama, alat tulis dan alsinta (alat mesin pertanian) yang meliputi mesin perontok, seed blower dan seed counter. Benih padi yang digunakan terdiri atas, 3 galur padi yaitu; 14 E 1002, 11S3, 14 E 1009. Setiap galur masing-masing 300 gram benih. Insektisida yang digunakan dalam penelitian ini adalah furadan, timex dan bentan 45 WP. Furadan bertujuan untuk membasmi hama serangga, Timex untuk membasmi tikus dan Bentan 45 WP untuk membasmi keong mas. Pupuk yang digunakan dalam penelitian ini yaitu NPK, Urea dan KCl.

\section{Pelaksanaan Penelitian}

\section{Persiapan Lahan}

Persiapan lahan diawali dengan membersihkan lahan, kemudian dilakukan pengolahan tanah pertama yaitu membalikkan tanah dengan menggunakan traktor sambil membenamkan sisa-sisa tanaman ke dalam tanah. Seminggu kemudian dilakukan pengolahan tanah kedua yaitu meratakan lahan dengan menggunakan cangkul dan garu, lalu dibuat plot untuk persemaian. 


\section{Perlakuan Benih}

Benih direndam didalam air selama 24 jam kemudian benih dibilas dengan air mengalir dan ditiriskan dalam karung dan diperam dalam handuk lembab selama 2 x 24 jam sampai benih berkecambah atau sampai keluar calon akar.

\section{Persemaian}

Bedeng persemaian dibuat dengan ukuran lebar $1 \mathrm{~m}$ dan panjang $38,6 \mathrm{~m}$, pengolahan tanah menggunakan tenaga manusia. Seluruh areal persemaian dikelilingi dengan pagar plastik untuk menghindari serangan tikus. Bedengan persemaian dipupuk dengan NPK sebanyak $1130 \mathrm{~g} /$ plot dan Urea sebanyak $560 \mathrm{~g} /$ plot sebagai pupuk dasar. Bersamaan dengan pemberian pupuk dasar diberikan juga furadan sebanyak $193 \mathrm{~g} / \mathrm{plot}$.

Setiap kantong benih diberikan label kode lapangan untuk dikecambahkan dan label atau identitas tersebut tidak boleh lepas dari kantong benih sampai benih selesai ditabur. Selanjutnya setiap kantong kecambah ditempatkan pada setiap bedeng persemaian yang telah diberi label yang sama dengan label pada kantong kecambah. Selanjutnya benih ditabur secara terpisah untuk setiap perlakuan (kode lapangan) pada masing-masing bedeng persemaian yang telah diberi label yang sama. Kode bedeng persemaian juga dibuat pada denah kertas dan disimpan untuk menghindari kesalahan penempatan benih. Pada umur 8 hari setelah semai dilakukan pemupukan susulan pertama dengan pupuk Urea sebanyak $280 \mathrm{~g} / \mathrm{plot}$. Pemupukan susulan kedua dilakukan pda umur bibit 17 hari setelah semai dengan menggunakan pupuk Urea sebanyak $140 \mathrm{~g} /$ plot.

\section{Penanaman}

Sebelum dilakukan penanaman terlebih dahulu tanah diratakan dengan menggunakan hand traktor, selanjutnya dibuat plot dengan menggunakan cangkul dengan ukuran plot 4x4 m (16 $\mathrm{m}^{2}$ ) sebanyak 9 plot.

Penanaman dilakukan setelah padi berumur 20 hari setelah semai atau telah mempunyai 46 helai daun. Benih dicabut dengan hati-hati agar tidak merusak perakaran karena sangat berpengaruh terhadap pertumbuhan. Setiap lubang ditanam sebanyak satu batang dengan jarak tanam $20 \mathrm{~cm}$ x $20 \mathrm{~cm}$. Setiap satu plot terdapat 400 batang tanaman padi.

\section{Pemupukan}

Pemupukan dilakukan sebanyak 4 kali dengan menggunakan pupuk Urea, $\mathrm{KCl}$, dan NPK. Pemupukan pertama diberikan pada hari penanaman dengan menggunakan pupuk NPK sebanyak $1200 \mathrm{~g} / \mathrm{plot}$ atau setara $750 \mathrm{~kg} / \mathrm{ha}$. Urea sebanyak $160 \mathrm{~g} / \mathrm{plot}$ atau setara dengan 100 $\mathrm{kg} / \mathrm{ha}$ dan Furadan sebanyak 19,2 g/plot atau setara dengan $12 \mathrm{~kg} / \mathrm{ha}$. Pemupukan susulan pertama dilakukan seminggu setelah tanam dengan menggunakan Urea sebanyak $160 \mathrm{~g} / \mathrm{plot}$ atau setara dengan $100 \mathrm{~kg} / \mathrm{ha}$. Pemupukan susulan kedua dilakukan pada umur 34 hari setelah tanam dengan menggunakan Urea sebanyak $120 \mathrm{~g} / \mathrm{plot}$ atau setara dengan $75 \mathrm{~kg} / \mathrm{ha}$, dan $\mathrm{KCl}$ sebanyak $240 \mathrm{~g} / \mathrm{plot}$ atau setara dengan $150 \mathrm{~kg} / \mathrm{ha}$. Pemupukan susulan ketiga dilakukan pada umur 58 hari setelah tanam dengan menggunakan Urea $160 \mathrm{~g} / \mathrm{plot}$ atau setara dengan 100 $\mathrm{kg} / \mathrm{ha}$.

6. Pemeliharaan

Pemeliharaan tanaman padi meliputi pengairan, pengendalian hama dan gulma. Pada saat tanam, air diberikan setinggi $2-5 \mathrm{~cm}$ dari permukaan tanah. Pada saat fase pembentukan anakan air dipertahankan dengan ketinggian 3-5 cm. Penyiangan gulma dilakukan pada saat tanaman padi berumur 40 hari setelah tanam. Penyiangan dilakukan dengan mencabut gulma yang tumbuh dan membenamkannya ke dalam tanah.

\section{Pemanenan}

Pemanenan dilakukan saat bulir gabah sudah masak penuh. Kriteria padi sudah dapat dipanen antara lain seluruh bagian tanaman sudah berwarna kuning, batang mulai mengering, tangkai sudah merunduk, gabah yang yang diambil sudah sulit dipecahkan dengan kuku, bila gulir gabah ditekan akan terasa keras. Pemanenan dilakukan dengan menggunakan sabit 
dengan cara memotong padi ditengah batangnya. Selanjutnya padi dirontokkan dengan mesin perontok untuk mendapatkan gabah kering.

\section{Pengamatan}

Pengamatan dilakukan pada 10 tanaman sampel. Peubah yang diamati dalam penelitian meliputi:

1. Tinggi tanaman $(\mathrm{cm})$

Tinggi tanaman mulai diamati pada umur 2 sampai 7 MST diamati seminggu sekali. Pengukuran dilakukan dari pangkal batang sampai dengan ujung tajuk tertinggi dengan menggunakan meteran dalam satuan $\mathrm{cm}$.

2. Jumlah anakan

Jumlah anakan dihitung pada umur 2 sampai 7 MST diamati seminggu sekali.

3. Umur berbunga (hari)

Umur berbunga dihitung jumlah hari dari saat pindah tanam sampai mencapai $10 \%$ dari populasi padi dalam setiap plot sudah berbunga.

4. Umur panen (hari)

Umur panen dihitung jumlah hari dari saat pindah tanam sampai malai/butir gabah padi menguning dalam populasi masak $80 \%$.

5. Panjang malai $(\mathrm{cm})$

Panjang malai diukur dari buku terakhir sampai ujung malai dengan menggunakan meteran yang diukur setelah panen.

6. Berat 1000 butir gabah $(\mathrm{g})$

Berat 1000 butir gabah diamati dengan memisahkan 1000 butir kemudian ditimbang dengan timbangan analitik.

7. Persentase gabah berisi per rumpun $(\%)$

Pengamatan persentase gabah berisi per rumpun dilakukan saat panen dengan menggunakan rumus sebagai berikut: $\frac{\text { Jumlah gabah berisi per rumpun }}{\text { Jumlah total gabah per rumpun }} \times 100 \%$

8. Persentase gabah hampa per rumpun (\%)

Pengamatan persentase gabah hampa per rumpun dilakukan saat panen dengan menggunakan rumus sebagai berikut: $\frac{\text { Jumlah gabah hampa per rumpun }}{\text { Jumlah gabah total per rumpun }} x 100 \%$

9. Berat gabah berisi per rumpun (g)

Gabah berisi yang telah dipisahkan dari gabah hampa ditimbang dalam satuan gram (g).

10. Berat gabah berisi per plot $(\mathrm{kg})$

Berat gabah per plot ditimbang setelah semua padi dijemur dan dalam keadaan gabah kering giling $(\mathrm{GKG})$ kadar air $15 \%$.

11. Potensi hasil per Ha.

Berat gabah kering giling merupakan konversi dari berat gabah per plot

$$
\frac{\text { Berat gaba h per plot }}{\text { Luas plot }} \times 10000
$$

\section{HASIL DAN PEMBAHASAN}

\section{Hasil Penelitian}

Hasil analisis ragam (Lampiran 4, 6, 8, 10, 12, 14 dan 28) menunjukkan bahwa galur berpengaruh sangat nyata terhadap tinggi tanaman umur 3, 4, 5, 6, 7 dan 8 MST, serta ratarata panjang malai. Selanjutnya galur potensial juga menunjukkan berpengaruh yang nyata 
terhadap tinggi tanaman umur 2 MST, jumlah anakan umur 4 dan 7 MST, dan rata-rata berat 1000 butir gabah (Lampiran 2, 20, 26, dan 30). Galur tidak berpengaruh nyata terhadap peubah lainnya yang meliputi jumlah anakan 2, 3, 5, dan 6 MST (Lampiran 16, 18, 22, dan 24).

\section{Tinggi Tanaman}

Hasil analisis ragam (Lampiran 2, 4, 6, 8, 10, 12 dan 14) menunjukkan bahwa galur berpengaruh sangat nyata terhadap tinggi tanaman umur $3-8$ MST dan berpengaruh nyata terhadap tinggi tanaman umur 2 MST. Rata-rata tinggi tanaman dari beberapa galur tanaman padi $2-8$ MST disajikan pada tabel 2 .

Tabel 2. Rata-rata tinggi $(\mathrm{cm})$ beberapa galur tanaman padi pada musim tanam gadu umur 2 sampai 8 MST.

\begin{tabular}{|c|c|c|c|c|c|c|c|c|}
\hline \multirow{2}{*}{ No } & \multirow{2}{*}{ Galur } & \multicolumn{7}{|c|}{ Tinggi Tanaman ( cm ) } \\
\cline { 3 - 10 } & & 2 MST & 3 MST & 4 MST & 5 MST & 6 MST & 7 MST & 8 MST \\
\hline 1 & $14 \mathrm{E} 1002$ & $51,72 \mathrm{~b}$ & $59,7 \mathrm{~b}$ & $72,0 \mathrm{c}$ & $87,3 \mathrm{c}$ & $93,6 \mathrm{~b}$ & $98,7 \mathrm{~b}$ & $111,0 \mathrm{c}$ \\
\hline 2 & $14 \mathrm{E} 1009$ & $44,05 \mathrm{a}$ & $50,36 \mathrm{a}$ & $60,6 \mathrm{a}$ & $71,0 \mathrm{a}$ & $76,0 \mathrm{a}$ & $81,0 \mathrm{a}$ & $95,04 \mathrm{a}$ \\
\hline 3 & $11 \mathrm{~S} 3$ & $51,02 \mathrm{~b}$ & $58,3 \mathrm{~b}$ & $68,0 \mathrm{~b}$ & $79,3 \mathrm{~b}$ & $91,0 \mathrm{~b}$ & $99,0 \mathrm{~b}$ & $106,6 \mathrm{~b}$ \\
\hline \multicolumn{2}{|c|}{$\mathrm{BNJ}_{0,05 \%}$} & 4,05 & 2,8 & 2,86 & 2,2 & 4,6 & 5,15 & 4,2 \\
\hline
\end{tabular}

Ket: Angka yang diikuti oleh huruf yang sama pada kolom yang sama tidak berbeda nyata pada Uji BNJ pada taraf $5 \%$

Berdasarkan Tabel 2 dapat dijelaskan bahwa galur 14E1002 merupakan galur dengan tanaman tertinggi mulai dari $2-8 \mathrm{MST}$. Tinggi tanaman galur ini mencapai $111,06 \mathrm{~cm}$ pada 8 MST. Sedangkan galur 14E1009 merupakan galur dengan tinggi tanaman terendah dan tingginya hanya sebesar 95,04 cm pada 8 MST. Galur tanaman padi 14E1009 merupakan galur terendah dari setiap minggu pengamatan. Pola perubahan tinggi tanaman mulai umur 2 sampai 8 MST disajikan pada Gambar 1.

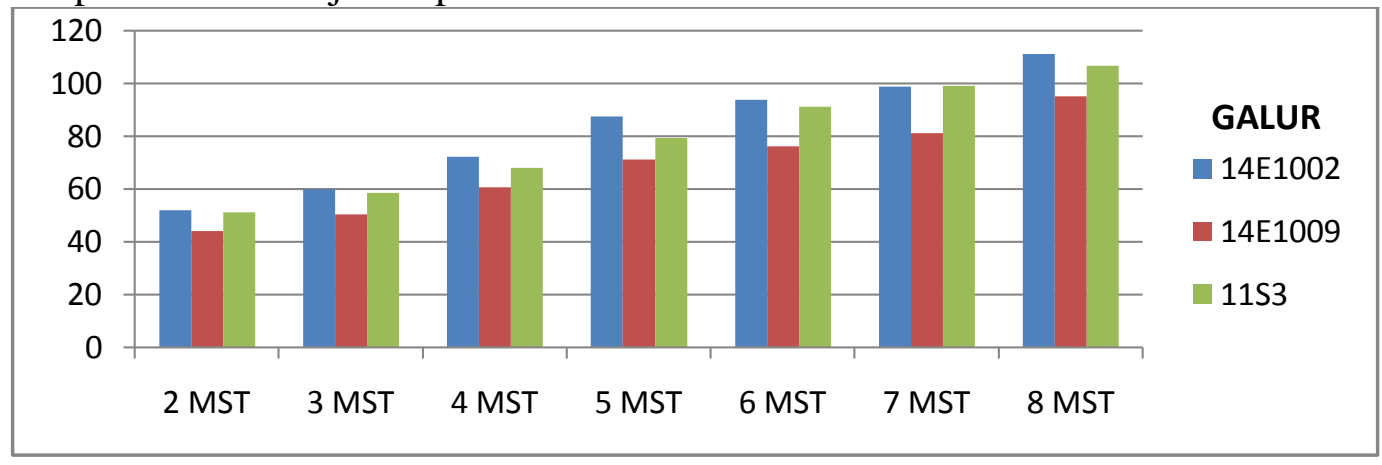

Tinggi Tanaman

Gambar 1. Rata-rata tinggi beberapa galur tanaman padi pada musim tanam gadu mulai umur 2 sampai 8 MST.

Berdasarkan Gambar 1, tanaman padi tertinggi dari umur 2 sampai 8 MST dijumpai pada galur 14E1002 kemudian diikuti oleh galur 11S3, sedangkan galur dengan tinggi tanaman terendah disetiap minggu dijumpai pada galur 14E1009.

\section{Jumlah Anakan}


Hasil analisis ragam (Lampiran 16, 18, 20, 22, 24 dan 26) menunjukkan bahwa galur berpengaruh sangat nyata terhadap jumlah anakan tanaman padi umur 4 dan 7 MST dan tidak berbeda nyata terhadap jumlah anakan tanaman padi pada umur 2, 3, 5 dan 6 MST. Rata-rata jumlah anakan galur tanaman padi dari umur 2, 3, 4, 5, 6 dan 7 MST dapat dilihat pada Tabel 3.

Tabel 3. Rata-rata jumlah anakan beberapa galur tanaman padi pada musim tanam gadu umur 2 sampai 7 MST.

\begin{tabular}{|c|c|c|c|c|c|c|c|}
\hline \multirow{2}{*}{ No } & \multirow{2}{*}{ Galur } & \multicolumn{7}{|c|}{ Jumlah Anakan } \\
\cline { 3 - 8 } & & $\begin{array}{c}\mathbf{2} \\
\text { MST }\end{array}$ & $\begin{array}{c}\mathbf{3} \\
\text { MST }\end{array}$ & $\begin{array}{c}\mathbf{4} \\
\text { MST }\end{array}$ & $\begin{array}{c}\mathbf{5} \\
\text { MST }\end{array}$ & $\begin{array}{c}\mathbf{6} \\
\text { MST }\end{array}$ & $\begin{array}{c}\mathbf{7} \\
\text { MST }\end{array}$ \\
\hline 1 & $14 \mathrm{E} 1002$ & 8,38 & 14,36 & $16,4 \mathrm{a}$ & 17,37 & 16,07 & $13,73 \mathrm{ab}$ \\
\hline 2 & $14 \mathrm{E} 1009$ & 11,72 & 20,38 & $23,69 \mathrm{~b}$ & 23,07 & 22,39 & $18,05 \mathrm{c}$ \\
\hline 3 & $11 \mathrm{~S} 3$ & 11,72 & 17,39 & $20,4 \mathrm{~b}$ & 21,08 & 19,36 & $12,06 \mathrm{a}$ \\
\hline \multicolumn{2}{|c|}{$\mathrm{BNJ}_{0,05 \%}$} & - & - & 3,75 & - & - & 3,06 \\
\hline
\end{tabular}

Ket: Angka yang diikuti oleh huruf yang sama pada kolom yang sama tidak berbeda nyata pada Uji BNJ pada taraf $5 \%$.

Berdasarkan Tabel 3 dapat diketahui bahwa rata-rata jumlah anakan galur tanaman padi yang diuji berkisar antara 17 sampai 23 anakan pada 5 MST. Hasil uji BNJ pada umur 2, 3, 5 dan 6 MST tidak ada perbedaan yang nyata, sedangkan pada umur tanaman padi 4 MST jumlah anakan terbanyak dijumpai pada galur 14E1009 dengan rata-rata $(23,69)$ yang berbeda nyata dengan galur 14E1002 dengan rata-rata $(16,4)$ anakan. Tetapi jumlah anakan 14E1009 tidak berbeda nyata dengan galur 11S3 dengan rata-rata $(20,4)$ anakan. Galur 14E1002 mempunyai anakan terendah pada umur 4 MST. Pada umur tanaman padi 7 MST jumlah anakan tanaman padi terbanyak dijumpai pada galur 14E1009 dan terendah pada galur 11S3. Galur 14E1009 mempunyai $(18,05)$ anakan, sedangkan galur 14E1002 dan 11S3 masingmasing hanya mempunyai jumlah anakan $(13,73$ dan 12,06). Pola perubahan jumlah anakan tanaman padi pada setiap galur umur 2 sampai 7 MST disajikan pada gambar 2.

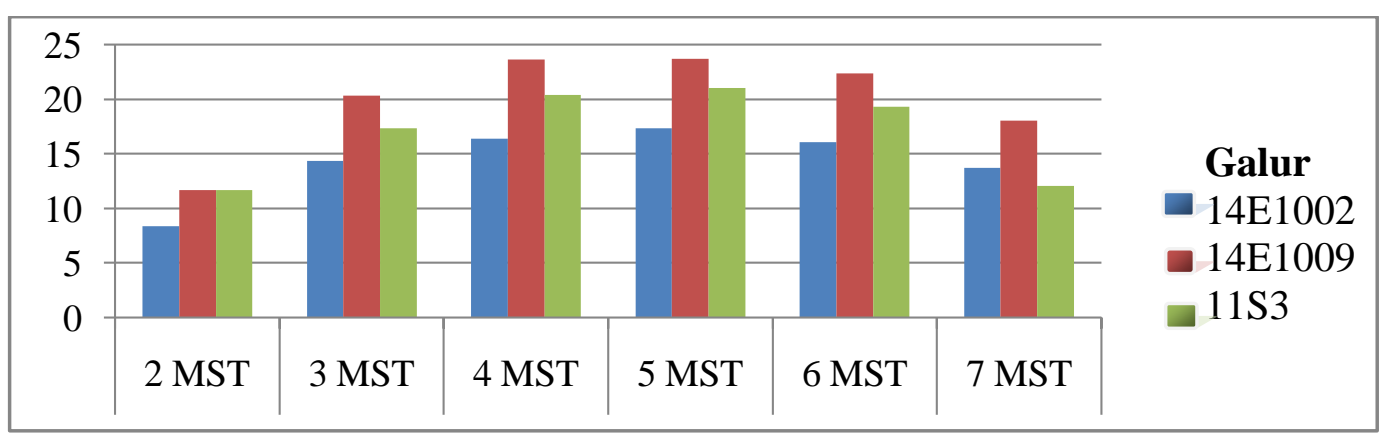

Gambar 2. Jumlah anakan beberapa galur tanaman padi pada musim tanam gadu umur 2 sampai 7 MST.

Berdasarkan Gambar 2, jumlah anakan tertinggi pada umur 2 sampai 7 MST dijumpai pada galur 14E1009 dan diikuti oleh galur 11S3, sedangkan anakan terendah setiap minggu dijumpai pada galur 14E1002 kecuali pada 7 MST. Puncak anakan tanaman padi tertinggi dijumpai pada umur 5 MST dari setiap galur, dan pada umur 6 sampai 7 MST anakan mulai menurun kembali.

\section{Umur Berbunga 10 Persen dan Umur Panen}


Berdasarkan hasil pengamatan umur berbunga dan umur panen galur tanaman padi Tabel 4 menunjukkan bahwa galur 14E1002 dan 14E1009 merupakan galur yang paling cepat berbunga yaitu pada umur 62 Hari Setelah Tanam (HST). Galur 11S3 berbunga pada umur 72 HST,

Tabel 4. Umur berbunga (10\%) dan umur panen galur tanaman padi

\begin{tabular}{|c|c|c|c|}
\hline No & Galur & Umur Berbunga 10 \% (hari) & Umur Panen(hari) \\
\hline 1 & $14 \mathrm{E} 1002$ & 62 & 102 \\
\hline 2 & $14 \mathrm{E} 1009$ & 62 & 102 \\
\hline 3 & $11 \mathrm{~S} 3$ & 72 & 113 \\
\hline
\end{tabular}

Berdasarkan Tabel 4 umur panen tanaman padi tercepat pada galur 14E1002 dan 14E1009 yaitu umur 102 HST, sedangkan galur yang paling lama umur panen yaitu 11S3 mencapai 113 HST. Perbandingan seluruh galur padi pada umur $10 \%$ berbunga dan umur panen pada berbagai galur disajikan pada gambar 3 .

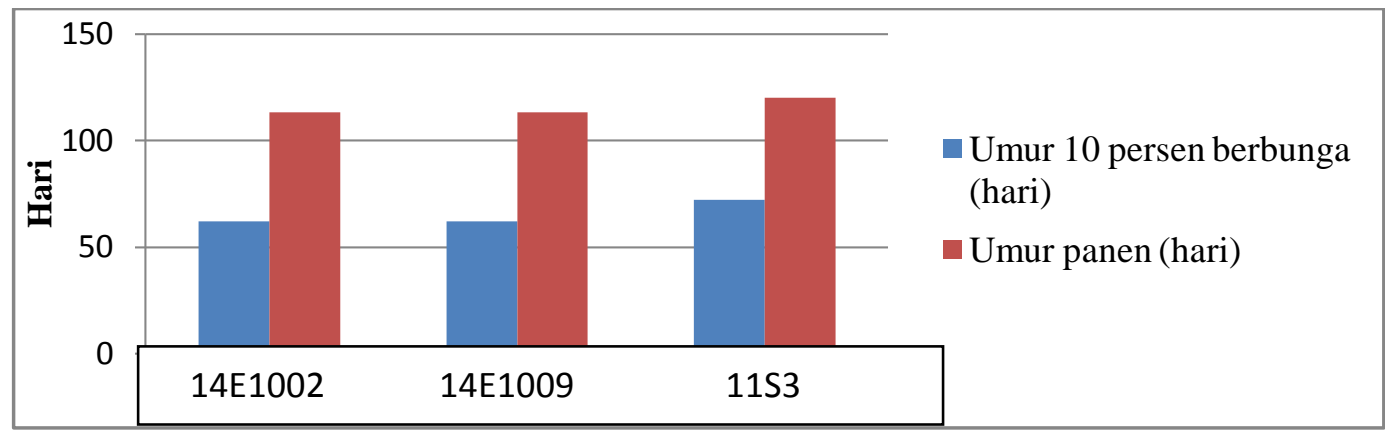

Gambar 3. Rata-rata umur berbunga dan umur panen tanaman padi.

\section{Panjang Malai}

Hasil analisis ragam (Lampiran 28) menunjukkan bahwa galur berpengaruh sangat nyata terhadap panjang malai tanaman padi. Rata-rata panjang malai tanaman padi per rumpun disajikan pada Tabel 5.

Tabel 5. Rata-rata panjang malai galur tanaman padi

\begin{tabular}{|c|c|c|}
\hline No & Galur & Panjang Malai (cm) \\
\hline 1 & 14E1002 & $24,03 \mathrm{ab}$ \\
\hline 2 & $11 \mathrm{E} 1009$ & $22,43 \mathrm{a}$ \\
\hline 3 & $11 \mathrm{~S} 3$ & $29,22 \mathrm{c}$ \\
\hline \multicolumn{2}{|c|}{$\mathrm{BNJ}_{0,05 \%}$} & 1,65 \\
\hline
\end{tabular}

Ket: Angka yang diikuti oleh huruf yang sama pada kolom yang sama tidak berbeda nyata pada Uji BNJ pada taraf $5 \%$. 
Berdasarkan Tabel 5 dapat dijelaskan bahwa galur 11S3 merupakan galur dengan panjang malai terpanjang yaitu $(29,22 \mathrm{~cm})$ yang berbeda sangat nyata dengan galur 14E1009 dan 14E1002, sedangkan 14E1009 merupakan galur yang memiki malai terpendek $(22,43$ $\mathrm{cm})$. Pola panjang malai pada setiap galur tanaman padi dapat dilihat pada Gambar 4.

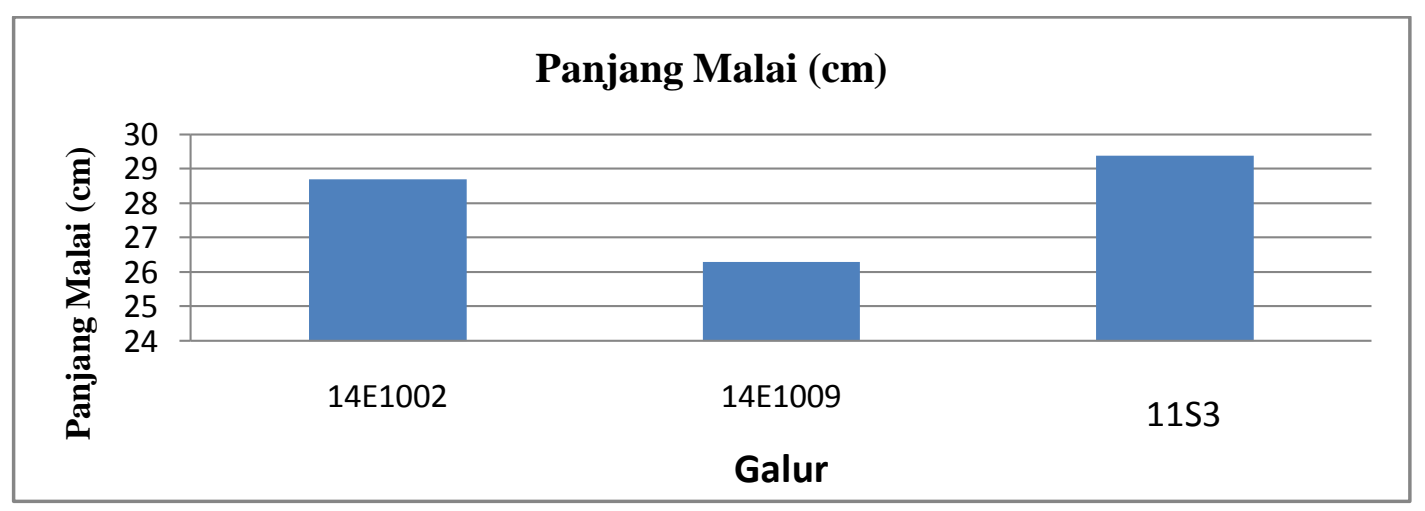

Gambar 4. Rata-rata panjang malai tanaman padi pada setiap galur.

\section{Berat 1000 Butir Gabah}

Hasil analisis ragam (Lampiran 30) menunjukkan bahwa galur tanaman padi berpengaruh nyata terhadap berat 1000 butir gabah, rata-rata berat 1000 butir gabah disajikan pada Tabel 6.

Tabel 6. Rata-rata berat 1000 butir gabah (g)

\begin{tabular}{|c|c|c|}
\hline No & Galur & Berat 1000 Butir Gabah (g) \\
\hline 1 & $14 \mathrm{E} 1002$ & $28,7 \mathrm{~b}$ \\
\hline 2 & 14E1009 & $26,3 \mathrm{a}$ \\
\hline 3 & $11 \mathrm{~S} 3$ & $29,4 \mathrm{~b}$ \\
\hline \multicolumn{2}{|c|}{ BNJ $0,05 \%$} & 1,16 \\
\hline
\end{tabular}

Ket: Angka yang diikuti oleh huruf yang sama pada kolom yang sama tidak berbeda nyata pada uji BNJ pada taraf $5 \%$

Berdasarkan Tabel 6 dapat dijelaskan bahwa berat 1000 butir gabah terberat dijumpai pada galur 11S3 yaitu $(29,4 \mathrm{~g})$ yang berbeda nyata dengan galur 14E1009 (26,3 g) yang merupakan galur terendah dari 3 galur yang diuji. Tetapi galur 11S3 tidak bebeda nyata dengan 14E1002 dengan rata-rata (28,7 g) pada uji BNJ. Rata-rata berat 1000 butir gabah padi pada setiap galur dapat dilihat pada Gambar 5.

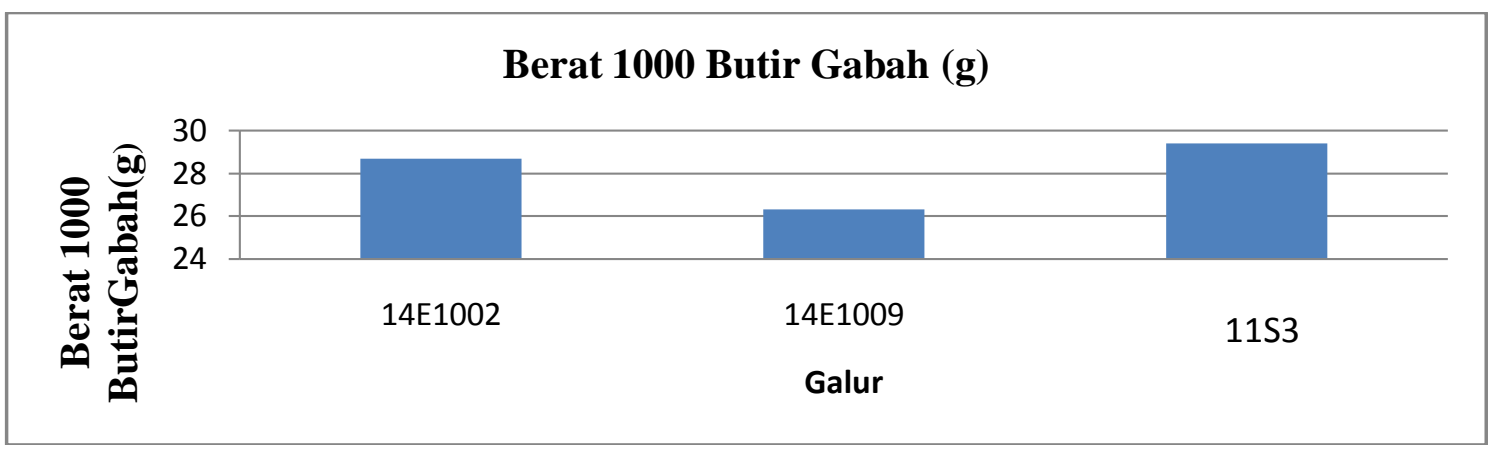


Gambar 5. Rata-rata Berat 1000 Butir Gabah Padi Pada Setiap Galur.

\section{Berat Gabah Berisi per Rumpun (g) dan Berat Gabah Berisi per Plot}

Hasil analisis ragam (Lampiran 32 dan 34) menunjukkan bahwa galur tidak berpengaruh nyata terhadap berat gabah berisi per rumpun dan berat gabah berisi per plot. Rata-rata hasil berat gabah per rumpun dan berat gabah per plot disajikan pada Tabel 7. Tabel 7. Rata-rata berat gabah per rumpun dan berat gabah per plot galur tanaman padi

\begin{tabular}{|c|c|c|c|}
\hline No & Galur & $\begin{array}{c}\text { Berat Gabah Berisi } \\
\text { per Rumpun (g) }\end{array}$ & $\begin{array}{c}\text { Berat Gabah Berisi } \\
\text { per Plot (kg) }\end{array}$ \\
\hline 1 & $11 \mathrm{E} 1002$ & 345 & 11,35 \\
\hline 2 & $14 \mathrm{E} 1009$ & 286 & 11,89 \\
\hline 3 & $11 \mathrm{~S} 3$ & 217 & 10,22 \\
\hline \multicolumn{2}{|c|}{ BNJ $_{0,05 \%}$} & - & - \\
\hline
\end{tabular}

Berdasarkan Tabel 7 dapat dijelaskan bahwa setiap galur tanaman padi 14E1002, 14E1009 dan 11S3 tidak berbeda nyata hasil berat gabah berisi per rumpun maupun berat gabah berisi per plot, meskipun secara statistik tidak berbeda nyata namun jika dilihat dari berat gabah galur 11S3 cenderung lebih rendah dari pengamatan berat gabah berisi perumpun maupun berat gabah berisi per plot dibandingkan berat gabah galur 14E1002 dan 14E1009.

\section{Persentase Gabah Hampa per Rumpun dan Persentase Gabah Berisi per Rumpun.}

Hasil analisis ragam (Lampiran 37 dan 38) Persentase gabah hampa dan persentase gabah berisi pada setiap galur tanaman padi yang diuji disajikan pada Tabel 8 .

Tabel 8. Rata-rata persentase gabah hampa dan gabah berisi per rumpun dari beberapa galur tanaman padi

\begin{tabular}{|c|c|c|c|}
\hline No & Galur & $\begin{array}{c}\text { Persentase gabah } \\
\text { hampa (\%) }\end{array}$ & $\begin{array}{c}\text { Persentase gabah berisi } \\
(\mathbf{\%})\end{array}$ \\
\hline 1 & $14 \mathrm{E} 1002$ & 20,41 & 79,59 \\
\hline 2 & $14 \mathrm{E} 1009$ & 21,77 & 78,23 \\
\hline 3 & $11 \mathrm{~S} 3$ & 30,14 & 69,86 \\
\hline
\end{tabular}

Berdasarkan Tabel 8 menunjukkan bahwa gabah hampa terbanyak dijumpai pada galur 11S3 yang diikuti oleh galur 14E1009 dan gabah hampa paling sedikit yaitu galur 14E1002. Sedangkan persentase gabah berisi terbanyak dijumpai pada galur 14E1002 dan diikuti oleh galur 14E1009, galur yang memiliki persentase gabah berisi paling rendah yaitu $11 \mathrm{~S} 3$.

Pola perbandingan galur padi yang diuji persentase gabah hampa per rumpun dan persentase gabah berisi per rumpun pada semua perlakuan disajikan pada Gambar 6 . 


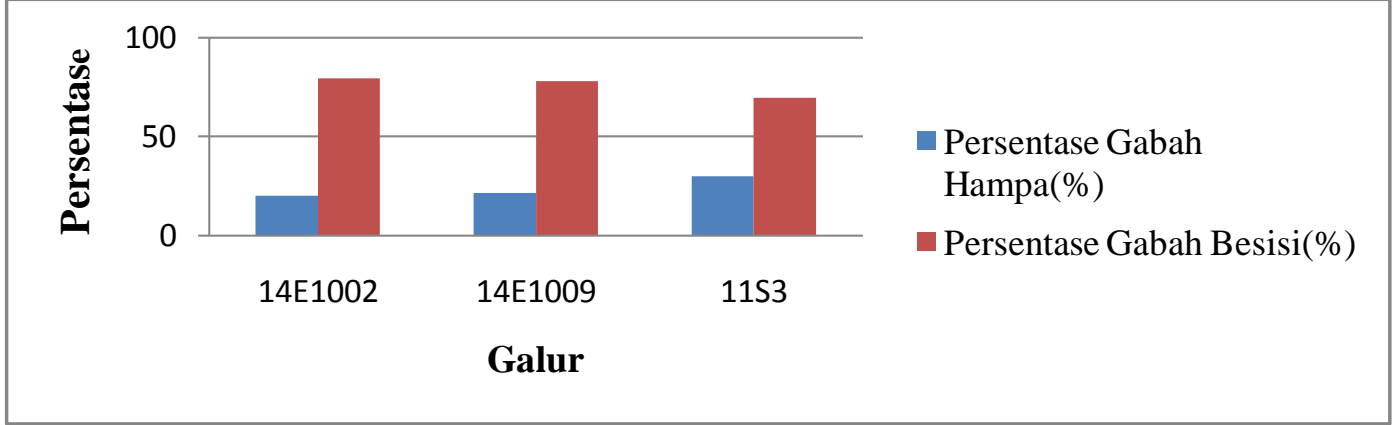

Gambar 6. persentase gabah hampa per rumpun dan persentase gabah berisi per rumpun.

\section{Potensi Hasil per Hektar}

Hasil analisis ragam (Lampiran 36) menunjukkan bahwa galur potensi hasil per hektar tanaman padi tidak berbeda nyata pada setiap galur. Rata-rata hasil potensi hasil tanaman padi per hektar pada setiap galur disajikan pada Tabel 9.

Tabel 9. Potensi hasil tanaman padi per hektar dari beberapa galur

\begin{tabular}{|c|c|c|}
\hline No & Galur & Potensi hasil per hektar (ton) \\
\hline 1 & $14 \mathrm{E} 1002$ & 7,09 \\
\hline 2 & $14 \mathrm{E} 1009$ & 7,43 \\
\hline 3 & $11 \mathrm{~S} 3$ & 6,39 \\
\hline & BNJ 0,05\% & - \\
\hline
\end{tabular}

Berdasarkan Tabel 9 dapat dijelaskan bahwa setiap galur tidak menununjukkan perbedaan yang nyata jumlah potensi hasil per hektar, namun potensi hasil perhektar galur 14E1009 yang diikuti oleh galur 14E1002 cenderung lebih tinggi, sedangkan galur 11S3 hasilnya lebih rendah. Pola perbandingan hasil potensi gabah per hektar setiap galur tanaman padi yang diuji dapat dilihat pada Gambar 7 .

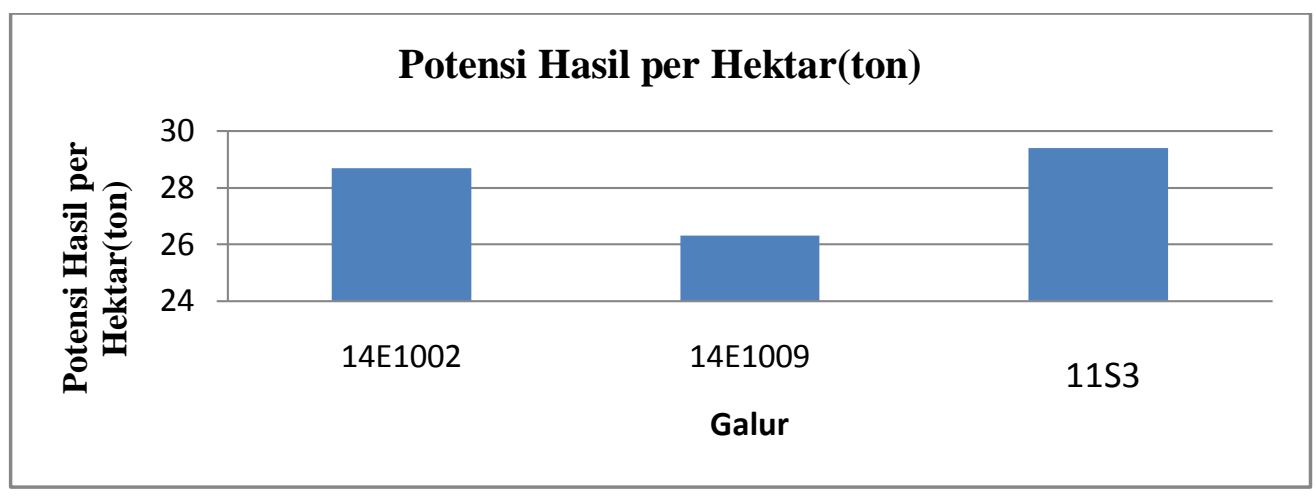

Gambar 7. Potensi Hasil Galur Tanaman Padi per Hektar.

\section{Pembahasan}

Pada umur tanaman padi 8 minggu setelah tanam (MST) tinggi galur-galur yang diuji berkisar antara 95,04 sampai 111,06 cm, galur 14E1002 merupakan galur tertinggi dan diikuti oleh galur 11S3, sedangkan galur terendah 14E1009. Menurut Vergara (1980), semakin tinggi tanaman semakin tinggi pula kecenderungan untuk rebah. Hasil galur-galur yang diuji pada penelitian ini menunjukkan tinggi yang sesuai dengan padi tipe baru dari beberapa referensi. Irsal et al. (2003) menyatakan bahwa varietas unggul tipe baru dirancang memiliki tinggi tanaman $90-110 \mathrm{~cm}$. Fagi et al. (2001) tinggi tanaman yang ideal untuk kriteria padi tipe 
baru (PTB) yaitu antara 80-100 cm, sedangkan Abdullah et al. (2006) menyatakan bahwa tinggi tanaman ideal PTB yaitu sedang-pendek $(110-100 \mathrm{~cm})$.

Menurut Silitonga et al. (1989) karakter tinggi tanaman yang diinginkan adalah heterosis negatif atau rendah, karena dengan demikian akan diperoleh tanaman-tanaman yang lebih pendek dari rata-rata kedua tetuanya, oleh karena itu kebanyakan pemulia tanaman memusatkan seleksi untuk tanaman yang lebih pendek untuk mengatasi kerebahan akibat tiupan angin yang kencang (Goldsworthy dan Fisher, 1992), diperkuat oleh Manurung et al., (1988), tanaman yang tinggi tanpa didukung oleh batang yang kuat dan kokoh akan rebah pada masa-masa awal pertumbuhan dan menjadi rebah sekali pada pemupukan $\mathrm{N}$ dosis tinggi. Tanaman yang rebah dapat menyebabkan tanaman banyak menghasilkan gabah hampa.

Pada peubah jumlah anakan, rataan jumlah anakan dari beberapa galur yang diuji pada umur 7 MST yaitu berkisar antara 12 sampai 18 anakan, anakan terbanyak dijumpai pada galur 14E1009 dengan rataan 18 anakan sedangkan terendah dijumpai pada galur 11S3 dengan rataan 12 anakan (Tabel 3). Jumlah anakan maksimum dicapai umur 5 MST, kemudian anakan yang terbentuk setelah mencapai batas maksimun akan berkurang. Ali Usman et al., (2004) menyatakan bahwa pada saat tanaman berada pada fase vegetatif, jumlah anakan berkisar antara 20 sampai 30, namun jumlah itu semakin lama semakin berkurang karena jumlah anakan yang terbentuk tidak semuanya dapat memasuki fase produktif.

Jumlah anakan produktif dari galur-galur yang diuji pada penelitian ini lebih banyak dari hasil penelitian sebelumnya sebagai mana Fagi et al., (2001) menyatakan bahwa salah satu sifat padi tipe baru (PTB) adalah memiliki anakan sedang (8-10 anakan) tetapi semuanya produktif, sedangkan Las et al., (2003) menyatakan bahwa padi tipe baru memiliki ciri jumlah anakan sedikit (7-12 batang) dan semuanya produktif.

Pada peubah umur 10 persen berbunga dan umur panen, galur yang paling cepat berbunga yaitu 14E1002 dan 14E1009 pada umur 63 Hari Setelah Tanam (HST), sedangkan galur 11S3 umur 10 persen berbunga mencapai 72 hari. Begitu juga pada umur panen, kedua galur ini 14E1002 dan 14E1009 mencapai umur panen lebih cepat yaitu 113 hari setelah tanam, sedangkan galur 11S3 umur panen lebih lama yaitu 120 hari setelah tanam. Dengan demikian galur 14E1002 dan 14E1009 mempunyai keunggulan dari sisi umur 10 persen berbunga dan umur panen. Menurut Umar (2008) umur $10 \%$ berbunga berkorelasi positif dengan umur tanaman atau masa panen, artinya galur/ varietas yang mempunyai umur $10 \%$ berbunga lebih pendek, maka umur masak galur/ varietas tersebut juga lebih pendek, atau biasa disebut dengan berumur genjah. Umur berbunga dan umur panen dipengaruhi oleh faktor genetik dari galur itu sendiri. Lingga (1991) menyatakan bahwa faktor genetik lebih dominan mengendalikan umur tanaman berbunga pertama dan umur tanaman saat panen bila dibandingkan dengan faktor luar seperti cahaya.

Pada peubah panjang malai, rata-rata panjang malai berkisar antara 22,43 sampai 29,22 $\mathrm{cm}$, malai terpanjang dijumpai pada galur 11S3 dan diikuti galur 14E1002, sedangkan yang terpendek dijumpai pada galur 14E1009 (Tabel 5). Dalam tanaman padi panjang malai ini mempunyai peranan penting karena berdasarakan pernyataan Siregar et al. (1998), malai yang panjang memungkinkan tempat kedudukan gabah lebih banyak, namun bila jumlah gabah hampa per malai tinggi, maka berat produksi per satuan luas akan rendah. Dengan demikian malai yang semakin panjang mempunyai peluang lebih tinggi produksi hasil per satuan luas karena semakin panjang malainya maka gabah atau bulir semakin banyak.

Tanaman padi ideal adalah yang mempunyai malai yang panjang dan lebat, dimana jumlah gabahnya banyak. Indeks kelebatan malai ditentukan oleh jumlah gabah total dan panjang malai. Semakin tinggi jumlah gabah total per malai, makin tinggi pula indeks kelebatan malai. Pada umumnya petani menyukai tanaman padi yang panjang dan lebat. Salah 
satu sifat padi tipe baru (PTB) adalah panjang malai lebih panjang dan lebat (300 butir/malai) (Las et al., 2003).

Pada peubah rata-rata berat 1000 butir berkisar antara 26,3 sampai 29,4 g, terberat dijumpai pada galur 11S3 dan diikuti oleh galur 14E1002 dan 14E1009. Pada peubah berat gabah berisi per rumpun terberat dijumpai pada galur 14E1002 dengan rataan (345 g) sedangkan berat gabah per plot terberat dijumpai pada galur 14E1009 dengan rataan $(11,89 \mathrm{~g})$ yang diikuti oleh galur 14E1002 (Tabel 7). Berat 1000 butir lebih ditentukan oleh bentuk gabah (Matshusima dan Muratha, 1970). Bentuk gabah yang lonjong dan besar akan mempunyai berat yang lebih besar bila dibandingkan gabah yang berbentuk bulat. Berat 1000 bulir gabah juga dipengaruhi oleh kondisi setelah pembungaan, misalnya tersedianya zat makanan, baik buruknya cuaca dan jumlah daun. Kondisi tersebut akan mempengaruhi banyak sedikitnya karbohidrat yang dihasilkan oleh proses fotosintesis dan selanjutnya akan menentukan ukuran gabah (Cahayaningsih, 2003).

Pada peubah persentase gabah berisi dan persentase gabah hampa menunjukkan bahwa galur 14E1002 mempunyai persentase gabah berisi tertinggi dan persentase gabah hampa terendah dengan persentase gabah berisi $(79,59 \%)$ sedangkan gabah hampa $(20,41 \%)$. Hasil sebaliknya menunjukkan bahwa galur 11S3 mempunyai persentase gabah berisi terendah dengan persentase $(69,86 \%)$ dan gabah hampa terbanyak yaitu $(30,14 \%)$, (Tabel 8). Cahayaningsih (2003) menyatakan bahwa jumlah gabah per malai dapat dipengaruhi oleh jumlah daun. Jumlah daun yang cukup diperlukan untuk menjamin banyaknya jumlah bulir. Jumlah bulir per malai juga dipengaruhi oleh stadia pertumbuhan. Faktor lingkungan yang ikut mempengaruhi yaitu suhu rendah dan sedikitnya cahaya yang tersedia pada stadia pembentukan malai akan meningkatkan jumlah bulir-bulir padi yang hampa. Kondisi iklim yang terus mendung dan banyak turun hujan akan memperlambat waktu masaknya gabah. Akan tetapi, cuaca kering, tidak banyak turun hujan, dan keadaan tanah yang mudah dikeringkan dari genangan air akan menyebabkan masaknya gabah lebih cepat (Sugeng, 2001). Sedangkan Li et al. (2002) menyatakan bahwa temperatur secara langsung berperan terhadap perkembangan biji seperti pengisian biji dan laju produksi bahan kering pada biji. Temperatur tinggi dapat menghambat perkembangan biji padi (Inaba dan Sato, 1976).

Pada peubah potensi hasil per hektar galur 14E1009 mempunyai hasil tertinggi yaitu (7,43 ton/ha) yang diikuti oleh galur 14E1002 (7,09 ton/ha) sedangkan galur potensi hasil per hektar terendah yaitu 11S3 dengan hasil (6,39 ton/ha). Karakter daya hasil yang ditunjukkan oleh 3 galur yang diuji menggambarkan bahwa galur tersebut masuk ke dalam kelompok genotipe yang mempunyai daya hasil tinggi. Menurut Astarini, (2008) padi sawah yang mempunyai daya hasil diatas 5 ton per hektar termasuk dalam kategori mempunyai potensi daya hasil tinggi.

Komponen yang menentukan dari banyaknya produksi tanaman terbaik yaitu persentase dari anakan produktif, bobot 1000 butir dan gabah isi (Gardner et al., 1991). Semakin banyaknya gabah yang terisi pada fase tersebut semakin banyak pula produktifitas padi per hektarnya. Upaya yang dapat dilakukan untuk meningkatkan produktivitas tanaman padi sawah adalah dengan menciptakan lingkungan tumbuh yang optimal untuk setiap fase pertumbuhan dan perkembangan tanaman (Djoyowasisto et al., 2007). Makarim dan Suhartatik (2009) menambahkan pada prinsipnya tanaman padi memiliki potensi hasil genetik, yaitu hasil tertinggi yang merupakan batas kemampuan suatu varietas padi dalam memproduksi gabah (produktivitas), yang dapat didicapai hanya pada kondisi iklim terbaik dan tanpa adanya faktor pembatas lingkungan tumbuh tanaman apapun.

\section{KESIMPULAN DAN SARAN}

\section{Kesimpulan}


1. Terdapat perbedaan pertumbuhan dan produktivitas seperti tinggi tanaman, panjang malai dan berat 1000 butir gabah dari ketiga galur yang diuji. Tanaman tertinggi dijumpai pada galur 14E1002, malai terpanjang dijumpai pada galur 11S3 dan berat 1000 butir tertinggi terdapat pada galur 11S3.

2. Galur 14E1009 dalam mencapai hasil per hektar lebih tinggi yaitu 7,43 ton per hektar pada musim tanam gadu.

\section{Saran}

1. Perlu dilakukan penelitian lebih lanjut terhadap galur-galur tanaman padi 14E1002, 14E1009 dan 11S3 pada berbagai musim tanaman, lokasi tanam serta berbagai kondisi sawah agar didapat data-data yang lebih akurat.

2. Dari hasil penelitian, maka perlu diperhatikan dan pengendalian maksimal terhadap hama terutama tikus, hal ini dilakukan untuk mengurangi terganggunya pertumbuhan tanaman dan potensi hasil yang dapat diperoleh.

\section{DAFTAR PUSTAKA}

Acquaah, G. 2007. Principles of Plant Genetics and Breeding. Blacwell Publishing. USA.

Astarini, I.A. 2008. Pemuliaan Tanaman Serealia. www.fp.unud.ac.id diakses 09 Maret 2016.

Cahyaningsih. 2003. Analisis Pertumbuhan Tanaman padi (Oryza sativa L) Pada Dosis Pupuk $\mathrm{N}$ yang Berbeda. Skripsi S1 Fakultas Pertanian Universitas Sebelas Maret Surakarta (unpublished).

Daradjat, A. A., Suwarno, B. Abdullah, Tj. Soewito, B.P. Ismail, dan Z.A. Simanullang. 2001. Status Penelitian Pemuliaan Padi Untuk Memenuhi Kebutuhan Pangan Masa Depan. Balai penelitian Tanaman Padi. Sukamandi.

Djoyowasito, G. Ekoyanto.P dan G. Maides . 2007. Mempelajari kinerja Pola tanam organik pada pertumbuhan dan produksi tanaman padi sawah (Oryza sativa L). Jurusan Teknologi Pertanian Universitas Barawijaya Malang. 10 (3): 200-204.

DKP-Aceh. 2013. Rumusan dan Komitmen Rapat Koordinasi Dewan ketahanan Pangan Aceh 2013. Banda Aceh, 6-7 November 2013.

Fagi, A. M., B. Abdullah, S. Kartaatmadja. 2001. Peran Padi Indonesia sebagai Sumber Daya Genetik Padi Modern. Prosiding Diskusi Panel dan Pameran Budaya Padi, Surakarta 28 Agustus 2001. Yayasan Padi Indonesia dan Indonesia Rice Foundation. p. 33-45.

Gardner, Franklin. P R B Pierce. RL Mitchel. 1991. Fisiologi Tumbuhan Budidaya. Terjemahan Herawati Susilo. Universitas Indonesia. Jakarta.

Golsworthy, P. R. dan N. M. Fisher. 1992. Fisiologi Tanaman Budidaya Tropik. Gadjah Mada University Press. Yogyakarta.

Inaba, K., and Sato, K. 1976. High Temperature Injury of Ripening in Rice Plant. VI. Enzymes Activities of kernel as Influenced by High Temperature. Proc. Crop. Sci. Soc. Jpn. 45:162:176. 
Irsal Las B. Abdullah, dan Aan Drajat. 2003.Padi Tipe Baru dan Padi Hibrida Mendukung Ketahanan Pangan .http://www.deptan.go.id/padi.

Las, I., B. Abdullah, dan A. Daradjat. 2003. Padi tipe baru dan hibrida mendukung ketahanan pangan. Tabloid Sinar Tani. 30 Juli 2003.

Li, X. Z., Liang, M. Z. And Zhou, G. Q. 2002. Effect of Environment Condition on Pollen Activity and seed Set During Flowering Time of Rice. Acta Agron. Sin. 28:417420 (in Chinese).

Lingga. 1991. Petunjuk Penggunaan Pupuk. Penebar Swadaya. Jakarta.

Makarim, K.A dan Suhartatik, E. 2009. Morfologi dan Fisiologi Tanaman Padi. Balai Besar Penelitian Tanaman Padi. www.litbang.deptan.go.id. [13 Maret 2016].

Manurung, S.O., M. Ismunadji. 1988. Morfologi dan fisiologi padi, hal : 55-102. Dalam Buku Padi 1. Puslitbang Tanaman Pangan. Bogor.

Matshusima dan Muratha, 1980). Fisiologi dan Moroflogi Tanaman Padi (buku 1). Balitan Pangan. Bogor.

Simanulang, ZA., Tjubaryat dan E. Suamadi. 1995. pemanduan beberapa sifat baik IR64.Pros. Seminar Apresiasi Hasil Penelitian Padi. Balitpa, Sukamandi.

Siregar, H. Endang S dan Soewito.1998. Analisis Beberapa sifat Galur Padi Sawah Dua

Musim Tanam Pusakanegara. Penelitan Pertanian Tanaman Pangan. Vol 17 (1): 38-44

Sudarna. 2010. Teknik pengujian daya hasil lanjutan beberapa galur harapan padi sawah tipe baru. Bul. Tek. Pertanian. 15(2): 48-51.

Umar.,S. 2008. Variasi Genetik, Heritabilitas, dan Korelasi Genotipik Sifat-sifat Penting Tanaman Wijen (Sesamum indicum L.). J. Littri 13 (3): 88-92.

Usman A, Rusdiansyah dan Sadarudin. 2004. Pertumbuhan dan Hasil Tanaman Padi (Oryza sativa L) Pada Lahan Sawah Tadah Hujan Akibat Umur Bibit dan Jarak Tanam yang Berbeda. Jurnal Budidaya Pertanian 10 (2) hal 104-112.

Vergara, B.S. 1980. Rice Plant Growth and Development. In B.S. Luh (Ed.) 